2. Муратова И.В., Данилова Н.В. Характеристика и методика развития основных физических качеств: учебнометодическое пособие; Саран, кооперативный институт РУК. - Саранск, 2019. - 94 с.

3. Наставление по физической подготовке в войсках национальной гвардии Российской Федерации (НФП 2018). $-77 \mathrm{c}$.

4. Руководство по физической подготовке в войсках национальной гвардии Российской Федерации. Москва. 2018. $-310 \mathrm{c}$.

5. Слабоучикова Т.А. Совершенствование физических качеств сотрудников полиции средствами кросс фита: методическое пособие; Екатеринбург: Уральский юридический институт МВД России, 2015. - 40 с.

\title{
Ступоченко Е.В. \\ Неформальный лидер как деструктивный фактор в процессе военно-патриотического воспитания подростков
}

ГБПОУ МО «Подольский колледж им. А.В. Никулина»

(Россия, Подольск)

doi: 10.18411/trnio-11-2021-181

\section{Аннотация}

В статье рассматривается проблема неформального лидерства в коллективе кадетского класса общеобразовательной школы как психолого-педагогический феномен. Источниками информации являлись опросы преподавателей и офицеров-воспитателей кадетских классов. Задачи исследования: обосновать важность поиска и разработки новых методов решения проблемы неформального лидерства, выявить основные факторы, оказывающие влияние на успешность и результативность. Гипотеза исследования: разработка и внедрение на имеющемся научном опыте новых методик взаимодействия с неформальными лидерами позволит обеспечить результативность учебно-воспитательного процесса. Методы исследования: дискурсивный анализ, сравнительно-сопоставительный анализ, систематизация, обобщение. Результаты: представлено обоснование важности разработки и внедрения новых методик взаимодействия с неформальными лидерами, проведен анализ, позволивший выявить основные факторы, оказывающие влияние на успешность воспитательной работы: разнообразие методов и форм взаимодействия с неформальным лидером; влияние профессиональных и личностных качеств преподавателя и офицера-воспитателя на неформального лидера.

Ключевые слова: неформальный лидер, военно-патриотическое воспитание, кадетский класс, воспитание.

\section{Abstract}

The article deals with the problem of informal leadership in the collective of cadet units of a secondary school as a psychological and pedagogical phenomenon. The questioning of teachers and education officers of cadet units served as the source of information. Research objectives: to substantiate the importance of search and development of new methods solving the problem of informal leadership, to identify the main factors influencing the success and efficiency thereof. Research hypothesis: the development and introduction of new methods of interaction with informal leaders, as based on the available scientific experience, is supposed to ensure the effectiveness of the educational process. Research methods: discursive analysis, comparison and collation, systematisation, generalisation. Results: the authors present the substantiation of importance of developing and introducing new methods of interaction with informal leaders; the undertaken analysis made it possible to reveal the main factors influencing success of the educational work: a number of methods and forms of interaction with the informal leader; influence of professional and personal qualities of the teacher and the education officer on the informal leader.

Keywords: informal leader, military patriotic education, cadet unit, character building. 
Создаваемые коллективы военно-патриотической направленности, такие как кадетские классы в общеобразовательных школах, нередко сталкиваются с появлением феномена «неформальный лидер». Сам по себе кадетский класс предполагает повышенный уровень дисциплины и порядка. Но, набираемые в него вчерашние школьники, выпускники шестых классов, зачастую не имеют достаточного представления об условиях обучения и досуга, с которыми они столкнутся, поступив в кадетские классы. При этом, необходимо учитывать тот факт, что кадетский класс, это новообразованный коллектив, и отбор в него проводится в основном по результатам учебы за последний год. Существуют вступительные испытания, такие как физкультура, история и математика, которые носят, как правило, формальный характер. Профессионально-направленного конкурсного отбора на сегодняшний день не проводится. Проводя опрос среди сотрудников школьных коллективов, имеющих непосредственное отношение к кадетскому образованию, нами было установлено, что руководителями образовательных организаций должным образом не проводилась агитационная работа по повышению интереса у школьников к кадетскому образованию. И, как следствие, в момент набора нередко возникал дефицит желающих поступить в кадетские классы. Выходом из сложившейся ситуации служило снижение требований к кандидатам, что и приводило к тому, что в коллектив кадет попадали, в первую очередь, так называемые «трудные подростки». С самого начала учебного процесса такие подростки старались занимать доминирующие позиции в коллективе. Нередко цель оправдывала средства и, если кто-то сопротивлялся воле новоявленного лидера, то в ход шли любые меры, включая применение силы. В таких условиях вести учебный процесс преподавателям крайне сложно. Двоякость ситуации обуславливается тем, что, с одной стороны, эти подростки теперь кадеты и формально на них распространяется устав кадетского движения, предусматривающий дисциплину, взаимовыручку и взаимопомощь, стойкость к физическим и моральным нагрузкам 1[2. Устав кадетского класса//Раздел «обязанности кадет»], а с другой стороны это зачастую неподготовленные морально школьники, неотдающие себе отчет о своём новом социальном статусе и принятых на себя обязательствах. На фоне этих ошибок и возникающих противоречий в коллективах неформальные лидеры несут деструктивную функцию, идущую в разрез с задачами военно-патриотического воспитания коллектива. Этих неформальных лидеров можно условно разделить на две категории. Первая - это подростки, имеющие высокий уровень мотивации к военному делу и преуспевающие в учёбе, с задатками своего рода «политического лидерства». Подростки этой категории стремятся показать и утвердить своё превосходство перед одноклассниками, основываясь на своих сильных сторонах. Негативным фактором в этом случае можно считать желание испытывать определённое удовлетворение от «преклонения» перед своей личностью. Ко второй категории относятся подростки, имеющие определенные проблемы с учёбой, поведением, проявляющие агрессию и нигилизм и отрицающие любые проявления авторитета, как сверстников, так и взрослых. В нашей работе мы будем рассматривать вторую категорию неформальных лидеров, дадим определение самому термину «неформальный лидер», определим природу его поведения, цели и меры противодействия деструктивной деятельности.

Итак, неформальным лидером с деструктивным направлением деятельности в нашей статье мы определяем подростка, проявляющего агрессию по отношению к оппоненту, не признающего авторитета преподавателей и офицеров-воспитателей, верховенства так называемого «формального лидера» (назначенного офицером-воспитателем на командную должность), несоблюдающего нормы поведения, регулярно нарушающего дисциплину и распорядок дня в учебном заведении. Таким образом, необходимо понимание того факта, что неформальный лидер - это неотъемлемая часть новообразованного коллектива, который потенциально несет целый ряд проблем преподавателям и классному руководителю (офицеру-воспитателю). Кто они и почему становятся лидерами, обладающими авторитетом и властью в кадетском коллективе? 
Вопросами психологии неформального лидерства занимались и занимаются ведущие ученые, такие как А.С. Макаренко, А.А Реан, А.Н. Лутошкин, Л.И. Уманский и многие другие. Начальный этап изучения вопроса «неформального лидерства» лежит на психологии, давая объяснение поведению такого подростка. В области педагогики рассматривается более сложная задача, заключающаяся в выявлении неформальных лидеров и составление программ и технологий взаимодействия педагогов с такими подростками, а так же коррекции их поведения в подростковом коллективе. Изучая проблему неформального лидерства, мы в нашем исследовании ссылаемся на работы А.Я. Анцупова. В своих трудах он подчеркивает, что в психологии существует определенный перекос: «Мы изучаем только 51 \% человека человека хорошего. Остальные 49 \% человека - человека плохого практически не изучаются... Психологи плохое в человеке не изучают и нередко даже видеть не хотят... Психология зла практически не изучается» [2]. Поскольку в нашем исследовании мы определили неформального лидера как негативный фактор, то варианты взаимодействия преподавателей и офицеров-воспитателей с такими подростками и коррекции их поведения в первую очередь базируются на постулате, что эти подростки по умолчанию несут своим поведением деструктивизм в кадетский коллектив. На сегодняшний день, в условиях ограниченности воспитательной функции педагогов общеобразовательных школ, вопрос работы с такими подростками стоит особенно остро. К сожалению, многими преподавателями отмечается отсутствие эффективных методов работы с неформальными лидерами, а наработки отечественной педагогики времён СССР не адаптированы к современным реалиям.

Становление кадетских классов в современной России началось относительно недавно [3]. На фоне ослабевания интереса к суворовским и нахимовским училищам, где в основном кадеты живут и обучаются на казарменном положении, т.е. постоянно проживают на территории училища и выходят за его пределы в увольнение по выходным, праздникам и на каникулы, кадетские классы в общеобразовательных школах на этом фоне имеют определенные преимущества. Кадеты живут дома и посещают школы как обычные учащиеся. Но при этом, как и в суворовских училищах, в их распорядок дня вносятся дисциплинарные аспекты такие как утреннее построение, осмотр внешнего вида и проверка готовности к занятиям. Занятия начинаются с доклада о готовности к уроку командиром класса преподавателю. После основных уроков, в послеобеденное время проводятся уроки по специальной подготовке (огневая подготовка, строевая подготовка, физическая подготовка, военная история отечества, изучение уставов, тактическая подготовка (включающая в себя целый набор военных дисциплин)). Однако, стоит принять во внимание, что при поступлении в ВВУЗ (Высшие Военные Учебные Заведения) выпускники кадетских классов не пользуются привилегиями в отличии от выпускников Суворовских и Нахимовских училищ[4].

Ввиду относительно мягкого, в дисциплинарном плане, режима в кадетских классах общеобразовательных школ, офицерам-воспитателям приходится особенно строго требовать соблюдения дисциплинарных норм и правил поведения всеми кадетами. Во многом это обуславливается ещё и тем, что в распоряжении офицеров-воспитателей суворовских и нахимовских училищ имеется значительно больший спектр методов воздействия на учащихся и поддержания дисциплины, чем у их коллег из кадетских классов общеобразовательных школ. На этом фоне неформальные лидеры получают большую свободу для высвобождение своей деструктивной энергии. Необходимо учитывать, что в кадетские классы зачастую попадают подростки имеющие проблемы не только с учебой, но и с дисциплиной, родители которых в силу различных причин не могут оказывать воспитательного воздействия на своих детей. В результате чего, подросток, находящийся в сложном для себя пубертатном периоде, не находит правильного вектора применения своей энергии и направляет её по своему усмотрению. Становясь лидером в своём классе, завоевав авторитет среди одноклассников нарушением дисциплины, связанной со вступлением в 
конфронтацию с преподавателями, с применением силы против своих одноклассников, такой подросток и в кадетском классе будет стремиться занять прежний уровень в новом социуме.

Единственно верным постулатом в нашем исследовании выведен принцип: не договариваться с неформальным лидером. Любая попытка заключения договора будет истрактована в его сознании как слабость оппонента. Авторитет преподавателя или офицеравоспитателя в глазах не только неформального лидера, но и других учащихся, будет подорван и восстановить его будет чрезвычайно сложно. Вместо этого, предлагается, изучив личность такого подростка (причины деструктивного поведения, его семью, и прочее) направить его деструктивную энергию в созидательное русло. К примеру, можно сделать его ответственным за соблюдение порядка в расположении класса и соблюдением дисциплины на занятиях, с последующим назначением на командную должность. Нагружать его различными ответственными поручениями, с привлечением к выполнению его окружения. Таким образом неформальному лидеру дается возможность реализовать лидерский потенциал и упрочить своё положение в коллективе. Прибегать к дисциплинарному наказанию можно только в крайнем случае. Как показало наше исследование, конфронтация в подобных случаях мало результативная мера. Если подросток не желает связывать своё будущее с военной или гражданской службой, не идет на контакт и продолжает занимать деструктивную позицию, не взирая на все используемые приёмы, то в этом случае мы можем констатировать ошибочность принятого решения обучения в кадетском классе общеобразовательной школы. Решением вопроса возможно будет поступление в суворовское или нахимовское училище, где, как уже упоминалось, более широкий спектр воспитательных мер.

В качестве основных инструментов решения этой задачи можно предложить следующее:

— размещение наглядной агитации в школах, где функционируют кадетские классы. Постоянное участие кадет в школьных мероприятиях. Проведение регулярной агитационно-разъяснительной работы среди школьников и родителей младших классов;

- проведение конкурсного отбора среди кандидатов на поступление, где основную роль отводить профессионально-направленному и психологопедагогическому исследованию личности кандидата;

- при принятии на должность офицера-воспитателя в кадетский класс внимательно изучить личность и послужной список кандидата, характеристики с прежних мест службы и работы. Провести профессионально-педагогический отбор для работы с подростками силами сотрудников районных военных комиссариатов с получением их заключения;

- подготовка и инструктаж офицеров-воспитателей и преподавателей общих дисциплин с работой в кадетском классе на предмет требования соблюдения кадетами дисциплинарных норм и установленного поведения. В том числе ориентировать на работу с неформальными лидерами и группами;

- в графике послеобеденных занятий особый упор делать на изучение специальных дисциплин, но и не пренебрегать воспитательными дисциплинами, такими как этикет, бальные танцы, история искусств и др.;

широкая по своему спектру система мотивации «трудных подростков» к соблюдению дисциплинарных норм, включающая в себя упрощенную (но и многоступенчатую), а главное работающую, процедуру отчисления из кадетского класса за систематическое нарушение дисциплины;

- применение описанных выше индивидуально подобранных методик работы c неформальными лидерами, направленными на нивелирование их деструктивного влияния на кадетский коллектив; 
Таким образом, в работе с неформальными лидерами в кадетских коллективах на сегодняшний день отсутствуют адаптированные к сегодняшним реалиям и апробированные методики взаимодействия преподавателя и подростка. Относительная недавность создания в общеобразовательных школах кадетских классов обнаружила неподготовленность педагогических коллективов и отсутствие реальных технологий по работе в кадетских классах. Данная проблема, как показало наше исследование, требует глубокого изучения и поиска наиболее эффективных форм решения проблемы.

$$
\text { *** }
$$

1. Устав кадетского класса. Раздел «обязанности кадет» (Федеральный Государственный Образовательный Стандарт Основного Общего Образования. Приказ Министерства просвещения Российской Федерации от 31.05.2021 №287)

2. А.Я. Анцупов Основы Социально-психологических исследований. М; Гардарики, 2007 с. 56.

3. Департамент образования города Москвы. Приказ Об образовательном проекте «Кадетский класс в московской школе» №1045 от 02.09.2016г.

4. Приказ Министра обороны РФ №185 «Об утверждении Порядка и условий приёма в образовательные организации высшего образования, находящиеся в ведении Министерства обороны Российской Федерации» от 07.042015 . 